\title{
New Bonding Mode of (Dithioformato)phosphine Ligand: Synthesis, Reactivity and Crystal Structure of $\left[\mathrm{W}(\mathrm{CO})_{5}\left(\mathrm{PPh}_{2} \mathrm{CS}_{2}\right)\right] \mathrm{t}_{4} \mathrm{~N}$
}

\author{
Kuang-Hway Yih, Ying-Chih Lin,* Ming-Chu Cheng and Yu Wang \\ Department of Chemistry, National Taiwan University, Taipei, Taiwan 106, Republic of China
}

The phosphorus coordination of the diphenyl(dithioformato)phosphine ligand in $\left[\mathrm{W}(\mathrm{CO})_{5}\left(\mathrm{PPh}_{2} \mathrm{CS}_{2}\right)\right] \mathrm{Et}_{4} \mathrm{~N}, 1$ has been confirmed by an $\mathrm{X}$-ray diffraction analysis; alkylation of 1 at the $\mathrm{S}$ atom results in the formation of $\mathrm{W}(\mathrm{CO})_{5}\left[\mathrm{PPh} \mathrm{h}_{2}\left(\mathrm{CS}_{2} \mathrm{R}\right)\right]$, 4 in high yield.

The chemistry of a zwitterionic trialkylphosphonium dithiocarboxylate ligand, $\mathrm{PR}_{3}+\mathrm{CS}_{2}{ }^{-}$, with three possible coordination sites, has attracted considerable attention in recent years. ${ }^{1-8}$ Various bonding modes, which include monodentate coordination, 1,2 bidentate coordination by chelation ${ }^{3,4}$ and, in dinuclear complexes, bridging coordination ${ }^{5-7}$ in different fashions, are known. On the other hand, the chemistry of anionic dialkylphosphinodithioformates, $\mathrm{PR}_{2} \mathrm{CS}_{2}{ }^{-}$, is much less studied. The zirconium complex $\mathrm{Zr}\left(\eta-\mathrm{C}_{5} \mathrm{H}_{5}\right)_{2}\left[\eta^{2}\right.$ $\left.\mathrm{S}_{2} \mathrm{CP}\left(\mathrm{SiMe}_{3}\right)_{2}\right] \mathrm{Cl}$ is the only example ${ }^{8}$ reported in the litera- 


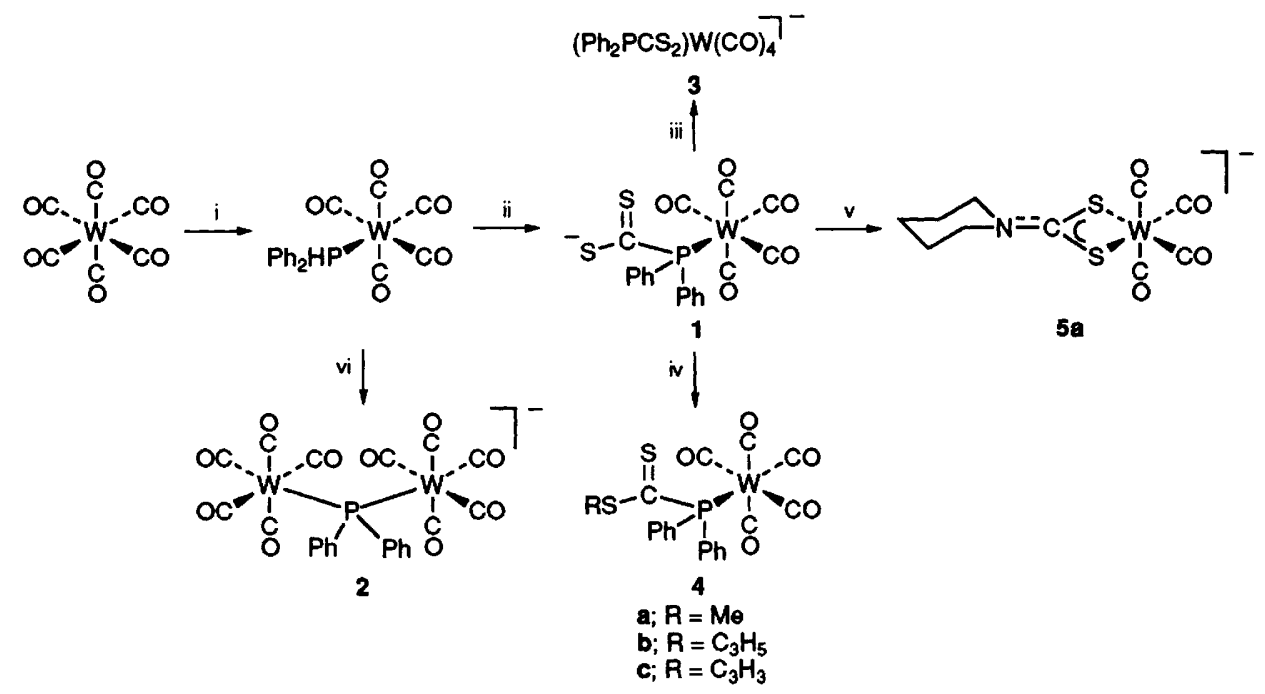

Scheme 1 Reagents and conditions: i, $\mathrm{Me}_{3} \mathrm{NO}, \mathrm{Ph}_{2} \mathrm{HP}, \mathrm{MeOH}, 25^{\circ} \mathrm{C}, 4 \mathrm{~h}$; ii, $\mathrm{Bu}{ }^{\mathrm{nLi}}, \mathrm{CS}_{2}, \mathrm{Et}_{4} \mathrm{NBr}, \mathrm{MeCN}, 25^{\circ} \mathrm{C}, 1 \mathrm{~min}$; iii, heat, THF, $2 \mathrm{~h}$; iv, RX, $\mathrm{CH}_{2} \mathrm{Cl}_{2}, 25^{\circ} \mathrm{C}, 1 \mathrm{~min}\left(\mathrm{R}=\mathrm{Me}, \mathrm{X}=\mathrm{I} ; \mathrm{R}=\mathrm{C}_{3} \mathrm{H}_{5}, \mathrm{X}=\mathrm{Br} ; \mathrm{R}=\mathrm{C}_{3} \mathrm{H}_{3}, \mathrm{X}=\mathrm{Br}\right) ; \mathrm{v},(\mathrm{pip}){ }_{2} \mathrm{~W}(\mathrm{CO})_{4}, \mathrm{MeCN}, 80^{\circ} \mathrm{C}, 1 \mathrm{~h} ; \mathrm{vi}$, $\mathrm{Bu}^{\mathrm{n}} \mathrm{Li}, \mathrm{Et}_{4} \mathrm{NBr}, \mathrm{MeCN}, 25^{\circ} \mathrm{C}$ (pip = piperidine)

ture. The two sulfur containing ligands bond to the metal centre exclusively through S-coordination in all of the reported complexes mentioned above. Herein we report a new coordination mode of the $\mathrm{PR}_{2} \mathrm{CS}_{2}$ - ligand, which is bonded to the metal through phosphorus-coordination with a $\sigma, \eta^{1}$-bonding mode.

Treatment of $\mathrm{W}(\mathrm{CO})_{5}\left(\mathrm{PPh}_{2} \mathrm{H}\right)$ with $\mathrm{Bu}^{\mathrm{n}} \mathrm{Li}$ and $\mathrm{CS}_{2}$ in the presence of $\mathrm{Et}_{4} \mathrm{NBr}$ afforded in $80 \%$ yield a red product, which was identified as $\left[\mathrm{W}(\mathrm{CO})_{5}\left(\mathrm{PPh}_{2} \mathrm{CS}_{2}\right)\right] \mathrm{Et}_{4} \mathrm{~N}, 1 .^{9}$ Satisfactory spectroscopic ${ }^{\dagger}$ and analytical data of 1 were obtained. In the 31P NMR spectrum of 1 , a resonance at $\delta 59.08$ with a

$\dagger$ Selected spectroscopic data: ${ }^{1} \mathrm{H}$ and ${ }^{13} \mathrm{C}-\left\{{ }^{1} \mathrm{H}\right\}$ NMR are recorded at $298 \mathrm{~K}$ in $\mathrm{CD}_{3} \mathrm{CN}$ and given as $\delta$ relative to $\mathrm{SiMe}_{4},{ }^{31} \mathrm{P}$ NMR data: $\mathrm{H}_{3} \mathrm{PO}_{4}$ external standard. For 1: IR $v / \mathrm{cm}^{-1}(\mathrm{KBr}), v(\mathrm{CO}): 2062 \mathrm{~m}$, $1979 \mathrm{~s}, 1947 \mathrm{~s}, 1904 \mathrm{vs} ; v(\mathrm{CS}): 1027 \mathrm{~s}$, 990w. ${ }^{31 \mathrm{P}} \mathrm{NMR}: 59.08\left({ }^{1} J_{\mathrm{W}-\mathrm{P}}\right.$ $238.24 \mathrm{~Hz}$ ). ${ }^{1} \mathrm{H}$ NMR: $1.18\left(\mathrm{tt}, 12 \mathrm{H}, \mathrm{N}-\mathrm{CH}_{2}-\mathrm{CH}_{3},{ }^{3} \mathrm{~J}_{\mathrm{N}-\mathrm{H}} 1.87,{ }^{3} J_{\mathrm{H}-\mathrm{H}}\right.$ $7.3 \mathrm{~Hz}), 3.10\left(\mathrm{q}, 8 \mathrm{H}, \mathrm{N}-\mathrm{CH}_{2}-\mathrm{CH}_{3},{ }^{3} J_{\mathrm{H}-\mathrm{H}} 7.3 \mathrm{~Hz}\right), 7.35(\mathrm{~m}, 6 \mathrm{H}, \mathrm{Ph})$, $7.66(\mathrm{~m}, 4 \mathrm{H}, \mathrm{Ph}) .{ }^{13} \mathrm{C}$ NMR: $7.6\left(\mathrm{~N}_{-} \mathrm{CH}_{2}-\mathrm{CH}_{3}\right), 53.0\left(\mathrm{~N}-\mathrm{CH}_{2}-\mathrm{CH}_{3}\right)$, $199.6(\mathrm{CO}), 255.4\left(\mathrm{CS}_{2}\right)$

2: IR $v / \mathrm{cm}^{-1}$ (THF), v(CO): 1993m, 1879vs, 1859sh, 1833s. ${ }^{31} \mathrm{P}$ NMR: $24.23\left({ }^{1} J_{\mathrm{W}-\mathrm{P}} 187.4 \mathrm{~Hz}\right) .{ }^{1} \mathrm{H}$ NMR: $1.17\left(\mathrm{tt}, 12 \mathrm{H}, \mathrm{N}-\mathrm{CH}_{2}-\mathrm{CH}_{3}\right.$, $\left.{ }^{3} J_{\mathrm{N}-\mathrm{H}} 1.87,{ }^{3} J_{\mathrm{H}-\mathrm{H}} 7.3 \mathrm{~Hz}\right) ; 3.13\left(\mathrm{q}, 8 \mathrm{H}, \mathrm{N}-\mathrm{CH}_{2}-\mathrm{CH}_{3}, 3 J_{\mathrm{H}-\mathrm{H}} 7.3\right), 7.43$ $(\mathrm{m}, 6 \mathrm{H}, \mathrm{Ph}), 7.69(\mathrm{~m}, 4 \mathrm{H}, \mathrm{Ph}) .{ }^{13} \mathrm{C}$ NMR: $7.5\left(\mathrm{~N}^{-} \mathrm{CH}_{2}-\mathrm{CH}_{3}\right), 52.8$ $\left(\mathrm{N}-\mathrm{CH}_{2}-\mathrm{CH}_{3}\right), 205.8,213.9,214.0,214.5,215.2(\mathrm{CO}), 264.6\left(\mathrm{CS}_{2}\right)$.

3a: IR v/cm ${ }^{-1}(\mathrm{KBr}), v(\mathrm{CO}): 2071 \mathrm{~m}, 1988 \mathrm{~s}, 1957 \mathrm{sh}, 1911 \mathrm{vs},{ }^{31} \mathrm{P}$ NMR: $64.26\left({ }^{1} J_{\mathrm{W}-\mathrm{P}} 248.0 \mathrm{~Hz}\right) .{ }^{1} \mathrm{H}$ NMR: $2.71\left(\mathrm{~s}, 3 \mathrm{H}, \mathrm{CH}_{3}\right), 7.50(\mathrm{~m}$, $6 \mathrm{H}, \mathrm{Ph}), 7.66(\mathrm{~m}, 4 \mathrm{H}, \mathrm{Ph}) .{ }^{13} \mathrm{C}$ NMR: $21.9\left(\mathrm{CH}_{3}\right), 198.1(\mathrm{~d}), 198.1$, $199.8,200.3(\mathrm{CO}), 240.3\left(\mathrm{CS}_{2}\right)$

3b: IR v/cm-1 (KBr), v(CO): 2070m, 1988s, 1929vs. ${ }^{31}$ P NMR: 64.49 (t, ${ }^{1} J_{\mathrm{W}-\mathrm{p}} 248.6 \mathrm{~Hz}$ ), ${ }^{1} \mathrm{H}$ NMR: $3.96,4.00\left(\mathrm{q}, 2 \mathrm{H}, \mathrm{S}-\mathrm{CH}_{2} \mathrm{CHCH}_{2}\right), 5.14$, $5.19,5.25,5.34\left(\mathrm{q}, 2 \mathrm{H}, \mathrm{S}-\mathrm{CH}_{2} \mathrm{CHCH}_{2}\right), 5.78\left(\mathrm{~m}, 1 \mathrm{H}, \mathrm{S}-\mathrm{CH}_{2} \mathrm{CHCH}_{2}\right)$, $7.53(\mathrm{~m}, 6 \mathrm{H}, \mathrm{Ph}), 7.68(\mathrm{~m}, 4 \mathrm{H}, \mathrm{Ph}) .{ }^{13} \mathrm{C}$ NMR: $41.0\left(\mathrm{~S}-\mathrm{CH}_{2} \mathrm{CHCH}_{2}\right)$, $121.0\left(\mathrm{~S}-\mathrm{CH}_{2} \mathrm{CHCH}_{2}\right), 129.6$, (Ph), $130.6\left(\mathrm{~S}-\mathrm{CH}_{2} \mathrm{CHCH}_{2}\right), 198.0$, $199.7,200.2(\mathrm{CO}), 238.3\left(\mathrm{CS}_{2}\right)$

3c: IR $v / \mathrm{cm}^{-1}(\mathrm{KBr}), v(\mathrm{CO}): 2073 \mathrm{~m}, 1957 \mathrm{~m}, 1919 \mathrm{vs}$. ${ }^{31} \mathrm{P}$ NMR: $64.64\left(\mathrm{t},{ }^{1} J_{\mathrm{W}-\mathrm{P}} 189.12 \mathrm{~Hz}\right) .{ }^{1} \mathrm{H}$ NMR: $2.47\left(\mathrm{t}, 1 \mathrm{H}, \mathrm{S}-\mathrm{CH}_{2} \mathrm{CC} H,{ }^{3} J_{\mathrm{H}-\mathrm{H}}\right.$ $2.89), 4.04\left(\mathrm{~d}, 2 \mathrm{H}, \mathrm{S}-\mathrm{CH}_{2} \mathrm{CCH}, 3 J_{\mathrm{H}-\mathrm{H}} 2.89\right), 7.48(\mathrm{~m}, 6 \mathrm{H}, \mathrm{Ph}), 7.69$ (m, $4 \mathrm{H}, \mathrm{Ph}) .{ }^{13} \mathrm{C}$ NMR: $26.6\left(\mathrm{~s}, \mathrm{SCH}_{2} \mathrm{CCH}\right), 72.7\left(\mathrm{~s}, \mathrm{SCH}_{2} \mathrm{CCH}\right)$, $75.8\left(\mathrm{~s}, \mathrm{SCH}_{2} \mathrm{CCH}\right), 196.9$ (d), $198.3,198.8(\mathrm{CO})$.

4a: IR $v / \mathrm{cm}^{-1}(\mathrm{KBr}), v(\mathrm{CO}): 1987 \mathrm{~m}, 1854 \mathrm{~m}, 1830 \mathrm{vs}, 1800 \mathrm{vs}, 1783 \mathrm{~s}$; $v(\mathrm{CN}): 1476 \mathrm{~m} .{ }^{1} \mathrm{H}$ NMR $\left(\mathrm{CD}_{3} \mathrm{CN}\right): 1.21\left(\mathrm{tt}, 12 \mathrm{H}, \mathrm{N}-\mathrm{CH}_{2}-\mathrm{CH}_{3},{ }^{3} J_{\mathrm{N}-\mathrm{H}}\right.$ $\left.1.87,{ }^{3} \mathrm{~J}_{\mathrm{H}-\mathrm{H}} 7.3 \mathrm{~Hz}\right), 1.59\left(\mathrm{~m}, 6 \mathrm{H}, \mathrm{N}-\mathrm{CH}_{2}-\mathrm{CH}_{2}-\mathrm{CH}_{2}\right), 3.15(\mathrm{q}, 8 \mathrm{H}$, $\left.\mathrm{N}-\mathrm{CH}_{2}-\mathrm{CH}_{3},{ }^{3} \mathrm{~J}_{\mathrm{H}-\mathrm{H}} 7.3 \mathrm{~Hz}\right), 3.82\left(\mathrm{~m}, 4 \mathrm{H}, \mathrm{N}-\mathrm{CH}-\mathrm{CH}_{2-}\right) .{ }^{13} \mathrm{C} \mathrm{NMR:} \delta$ $7.6\left(\mathrm{~N}-\mathrm{CH}_{2}-\mathrm{CH}_{3}\right), 24.7\left(\mathrm{~N}-\mathrm{CH}_{2}-\mathrm{CH}_{2}-\mathrm{CH}_{2}\right), 26.0\left(\mathrm{~N}-\mathrm{CH}_{2}-\mathrm{CH}_{2}\right), 47.5$ $\left(\mathrm{N}-\mathrm{CH}_{2}-\mathrm{CH}_{2}\right), 52.9\left(\mathrm{~N}-\mathrm{CH}_{2}-\mathrm{CH}_{3}\right), 204.0(\mathrm{CO}), 213.0\left(\mathrm{CS}_{2}\right), 213.8$ (CO).

4b: IR $v / \mathrm{cm}^{-1}$ (MeCN), v(CO); 2072m, 1937vs. ${ }^{31}$ P NMR: -10.31 $\left({ }^{1} J_{\mathrm{W}-\mathrm{P}} 224.58 \mathrm{~Hz}\right)$. ${ }^{1} \mathrm{H}$ NMR: $6.95\left(\mathrm{~d}, 1 \mathrm{H}, \mathrm{PH}, J_{\mathrm{P}-\mathrm{H}} 358 \mathrm{~Hz}\right), 7.47,7.67$ $(\mathrm{m}, 10 \mathrm{H}, \mathrm{Ph})$

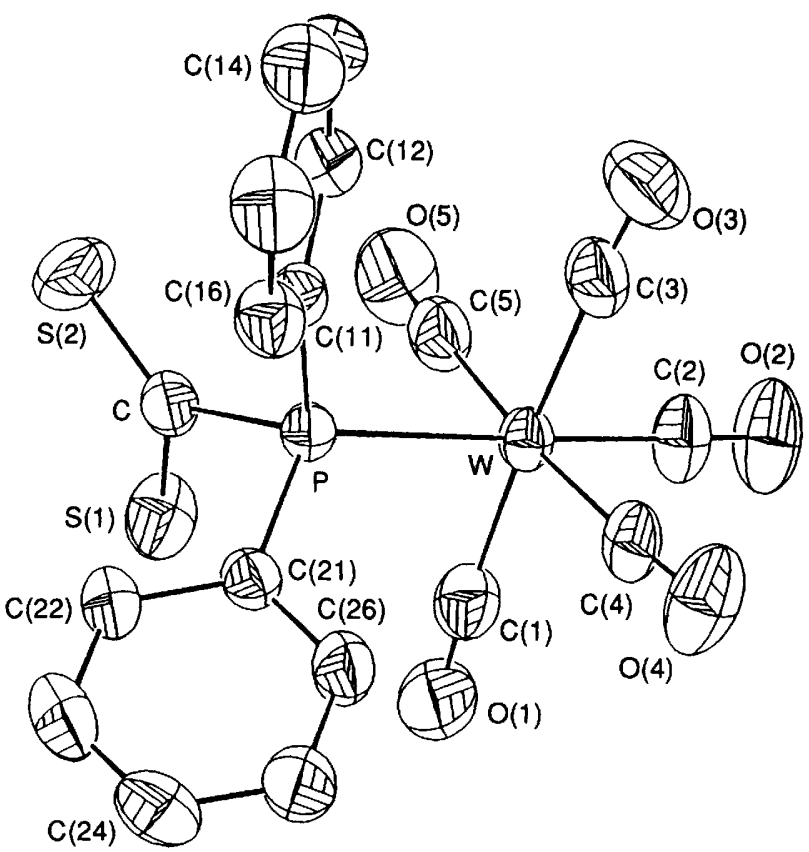

Fig. 1 ORTEP drawing for the anion of $\left[\mathrm{W}(\mathrm{CO})_{5}\left(\mathrm{PPh}_{2} \mathrm{CS}_{2}\right)\right] \mathrm{Et}{ }_{4} \mathrm{~N}, 1$ $\left(\mathrm{Ph}=\mathrm{C}_{6} \mathrm{H}_{5}\right)$, with thermal ellipsoids shown at the $50 \%$ probability level. Selected bond distances $(\AA)$ and bond angles $\left({ }^{\circ}\right)$ are as follows: W-P 2.553(1), P-C 1.872(5), C-S(1) 1.669(5), C-S(2) 1.650, W-S(1) 4.056(2), W-S(2) 4.946(2); C(4)-W-P 97.5(1), W-P-C 112.2(2), P-C-S(1) 112.7(3), P-C-S(2) 119.6(3).

tungsten satellite $\left({ }^{1} J_{\mathrm{W}-\mathrm{P}} 238.24 \mathrm{~Hz}\right)$ indicates phosphorus coordination of the ligand. The unusual bonding mode for the $\mathrm{PPh}_{2} \mathrm{CS}_{2}-$ ligand has been confirmed by an $\mathrm{X}$-ray diffraction study. $\ddagger$ The structure of the anion of 1 is shown in Fig. 1 . The

$\ddagger$ Crystal data for $1: \mathrm{C}_{26} \mathrm{H}_{30} \mathrm{NO}_{5} \mathrm{PS}_{2} \mathrm{~W}$, space group $P \overline{1}, a=10.688(3)$, $b=11.070(2), c,=12.785(2) \AA, \alpha=88.26(1), \beta=81.87(2), \gamma=$ $74.08(2)^{\circ}, V=1440.0(5) \AA^{3}, Z=2, D_{\mathrm{c}}=1.65 \mathrm{~g} \mathrm{~cm}^{-3}, \mu=$ $4.32 \mathrm{~mm}^{-1}$, observed reflections $4557,2 \theta_{\max }=2-49.8^{\circ}$. The structure was solved by using the heavy atom method, a series of difference Fourier maps and refined by least-squares refinements with $R=0.028$ and $R_{\mathrm{w}}=0.025$. Hydrogen atoms were included in the structure factor calculations in their expected positions on the basis of idealized bonding geometry but were not refined by least-squares. Atomic coordinates, bond lengths and angles, and thermal parameters have been deposited at the Cambridge Crystallographic Data Centre. See Notice to Authors, Issue No. 1. 
coordination geometry about the tungsten atom can be described as distorted octahedral. The $\mathrm{CS}_{2}$ unit is attached to the phosphorus atom through carbon with no bonding interaction between the tungsten metal centre and the sulfur atoms, the $\mathrm{W}-\mathrm{S}(1)$ and $\mathrm{W}-\mathrm{S}(2)$ distances are $4.056(2)$ and $4.946(2) \AA$, respectively. Obviously, 1 was formed by a deprotonation step followed by a nucleophilic attack at the carbon atom of $\mathrm{CS}_{2}$. In the reaction of $\mathrm{W}(\mathrm{CO})_{4}\left(\mathrm{NHC}_{5} \mathrm{H}_{10}\right)_{2}$ with $\mathrm{Bu}{ }^{\mathrm{n}} \mathrm{Li}$ and $\mathrm{CS}_{2}$, the $\mathrm{CS}_{2}$ insertion into the $\mathrm{W}-\mathrm{N}$ bond gave $\left[\mathrm{W}(\mathrm{CO})_{4}\left(\mathrm{~S}_{2} \mathrm{CNC}_{5} \mathrm{H}_{10}\right)\right] \mathrm{Et}_{4} \mathrm{~N}$ 5a. The insertion of $\mathrm{CS}_{2}$ into the $\mathrm{Pt}-\mathrm{F}$ bond of $\left[\mathrm{Pt}\left(\mathrm{PPh}_{3}\right)_{2} \mathrm{~F}\right]\left[\mathrm{HF}_{2}\right]$ gave $\left[\mathrm{Pt}\left(\mathrm{S}_{2} \mathrm{CF}\right)\left(\mathrm{PPh}_{3}\right)_{2}\right]$, where the dithiofluoroformate ligand coordinates to $\mathrm{Pt}$ through two $S$ atoms. ${ }^{10}$ To our knowledge, complex 1 is the first example of phosphorous coordination of the $\mathrm{PR}_{2} \mathrm{CS}_{2}{ }^{-}$ ligand.

The reaction of 1 with $\mathrm{MeI}$ in $\mathrm{CH}_{2} \mathrm{Cl}_{2}$ gave a neutral complex $\mathrm{W}(\mathrm{CO})_{5}\left[\mathrm{PPh}_{2}\left(\mathrm{CS}_{2} \mathrm{CH}_{3}\right)\right] \mathbf{4 a}$ in $80 \%$ yield. The alkylation takes place at the sulfur atom. In the ${ }^{13} \mathrm{C}$ NMR spectrum of $4 \mathrm{a}$, a singlet at $\delta 21.86$ is attributed to the Me of the $-\mathrm{CS}_{2} \mathrm{Me}$ group. ${ }^{11}$ Lack of $J_{\mathrm{P}-\mathrm{H}}$ coupling of this resonance contrasts with the observation of a doublet resonance $\left({ }^{2} J_{\mathrm{P}-\mathrm{C}}\right.$ $14.7 \mathrm{~Hz})^{12}$ for the methyl group of the compound [W( $\eta$ $\left.\left.\mathrm{C}_{5} \mathrm{H}_{5}\right)\left\{\mathrm{S}_{2} \mathrm{C}(\mathrm{Me}) \mathrm{PMe}_{3}\right\}(\mathrm{CO})_{2}\right]$ where the methyl group is bound to the carbon atom. The ${ }^{31} \mathrm{P}$ NMR spectrum of $\mathbf{4 a}$ shows a resonance at $\delta 64.26\left({ }^{1} J_{\mathrm{W}-\mathrm{P}} 247.95 \mathrm{~Hz}\right)$, close to that of 1. Two other alkylation products $\mathrm{W}(\mathrm{CO})_{5}\left[\mathrm{PPh}_{2}-\right.$ $\left.\left(\mathrm{CS}_{2} \mathrm{CH}_{2} \mathrm{CH}=\mathrm{CH}_{2}\right)\right], \quad 4 \mathrm{~b}$ and $\mathrm{W}(\mathrm{CO})_{5}\left[\mathrm{PPh}_{2}\left(\mathrm{CS}_{2} \mathrm{CH}_{2-}\right.\right.$ $\mathrm{C} \equiv \mathrm{CH})$, $4 \mathbf{c}$ from allylic bromide and propynyl bromide, respectively, were prepared. The resonances in the ${ }^{31} \mathrm{P}$ NMR spectra of $\mathbf{4 b}$ and $4 \mathrm{c}$ are at $\delta 64.49\left({ }_{\mathrm{W}-\mathrm{P}} 248.56 \mathrm{~Hz}\right)$ and $\delta$ $64.64\left({ }^{1} J_{\mathrm{W}-\mathrm{P}} 189.12 \mathrm{~Hz}\right)$, respectively. Complex $4 \mathrm{c}$ decomposed at room temp. in about $20 \mathrm{~min}$.

Thermolysis of 1 in tetrahydrofuran (THF) gave a cationic product identified as [W(CO) $\left.{ }_{4}\left(\mathrm{PPh}_{2} \mathrm{CS}_{2}\right)\right] \mathrm{Et}{ }_{4} \mathrm{~N}, 3$ based on its analytical and spectroscopic data (see Scheme 1). The IR spectra of 3 exhibits four absorption bands at 1993, 1879, 1859 and $1833 \mathrm{~cm}^{-1}$, a typical pattern for a cis-M(CO) ${ }_{4} \mathrm{~L}_{2}$ unit in octahedral geometry. In the mass spectrum of 3 , the molecular ion along with the $\mathrm{CO}$ fragmentations are detected with a highest observed peak at $\mathrm{m} / \mathrm{z} 817$ corresponding to the $\left[\mathrm{W}(\mathrm{CO})_{4}\left(\mathrm{PPh}_{2} \mathrm{CS}_{2}\right]\left[\mathrm{Et}_{4} \mathrm{~N}\right]_{2}{ }^{+}\right.$cation. The ${ }^{31} \mathrm{P} \mathrm{NMR}$ spectrum of 3 shows a resonance at $\delta 24.23$, again with a tungsten satellite $\left({ }^{1} J_{\mathrm{W}-\mathrm{P}} 187.4 \mathrm{~Hz}\right)$ indicating phosphorus coordination.
Compared with the $31 \mathrm{P}$ chemical shift of the compound 1 , the relatively up-field shift of this resonance suggests different chemical environments for the $\mathrm{PR}_{2} \mathrm{CS}_{2}-$ ligand in 1 and 3. A new chelation mode of the bidentate $\mathrm{PR}_{2} \mathrm{CS}_{2}-$ ligand i.e. chelation through the phosphorus and one of the sulfur atoms is proposed. The structure and chemical reactivity of $\mathbf{3}$ are currently under investigation.

Attempts to prepare a dinuclear complex using the $\mathrm{PR}_{2} \mathrm{CS}_{2}{ }^{-}$unit of 1 as a bridging ligand led to cleavage of the $\mathrm{P}-\mathrm{CS}_{2}$ bond. For example, in the reaction of 1 with [W(CO $)_{4}\left(\mathrm{NHC}_{5} \mathrm{H}_{10}\right)_{2}$ ], the $\mathrm{CS}_{2}$ of 1 inserted into the W-N bond of $\left[\mathrm{W}(\mathrm{CO})_{4}\left(\mathrm{NCH}_{5} \mathrm{H}_{10}\right)_{2}\right]$ to yield the known dithiocarbamate complex $\left[\mathrm{W}(\mathrm{CO})_{4}\left(\eta^{2}-\mathrm{S}_{2} \mathrm{CNC}_{5} \mathrm{H}_{10}\right)\right] \mathrm{Et}_{4} \mathrm{~N}$ 5a and the starting material $\mathrm{W}(\mathrm{CO})_{5}\left(\mathrm{PPh}_{2} \mathrm{H}\right) 5 \mathbf{b}$.

We thank the National Science Council of Taiwan, the Republic of China for support.

Received, 20th April 1993; Com. 3/02283H

\section{References}

1 C. Bianchini, C. A. Ghilardi, A. Meli, S. Midolini and A. Orlandini, Organometallics, 1982, 1, 778.

2 R. Uson, J. Fornies, R. Navarro, M. A. Uson, M. P. Garcia and A. J. Welch, J. Chem. Soc., Dalton Trans., 1984, 345.

3 C. Bianchini, A. Meli and A. Orlandini, Inorg. Chem., 1982, 21, 4161.

4 C. Bianchini, C. A. Ghilardi, A. Meli and A. Orlandini, Inorg. Chem., 1983, 22, 2188.

5 C. Bianchini, C. A. Ghilardi, A. Meli, A. Orlandini and G. Scapacci, J. Chem. Soc., Dalton Trans., 1983, 1969.

6 H. Werner, Coord. Chem. Rev., 1982, 43, 165.

7 L. F. Dahl and R. F. Rundle, Acta Crystallogr., 1963, 16, 419.

8 E. Hey, M. F. Lappert, J. L. Atwood and S. G. Bott, J. Chem. Soc., Chem. Commun., 1987, 421.

9 A yellow dimeric phosphido complex, $\left[\mathrm{W}(\mathrm{CO})_{5}\right]_{2}\left(\mu-\mathrm{PPh}_{2}\right), 2$, was also isolated in $15 \%$ yield, R. L. Keiter and M. J. Madigan, Organometallics, 1982, 1, 409.

10 J. A. Evans, M. J. Hacker, R. D. W. Kemmitt, D. R. Russell and J. Stocks, J. Chem. Soc., Chem Commun., 1972, 72.

11 C. Bianchini, A. Meli, P. Dapporto, A. Tofanari and P. Zanello, Inorg. Chem., 1987, 26, 3677.

12 F. R. Kreissi, N. Ullrich, A. Wirsing and U. Thewalt, Organometallics, 1991, 10, 3275. 